\title{
Eleştiren ve Eleştirilen Bir Sahabî Olarak Hz. Aişe*
}

\section{Hz. Aisha As A Critical And Criticized Companions}

\author{
Bünyamin Erul a,** \\ ${ }^{a}$ Prof. Dr. Ankara Üniversitesi, İlahiyat Fakültesi, Temel İslam Bilimleri Bölümü Hadis ABD, Ankara/Türkiye. \\ ORCID: 0000-0003-0630-4147.
}

\begin{tabular}{l} 
MAKALE BİLGİSİ \\
\hline Makale Geçmişi: \\
Başvuru tarihi: 30 Mart 2021 \\
Düzeltme tarihi: 10 Haziran 2021 \\
Kabul tarihi: 19 Haziran 2021 \\
\hline Anahtar Kelimeler: \\
Hz. Aişe \\
Tenkid \\
Sahâbe
\end{tabular}

\section{A R T I C LE INFO}

\section{Article history:}

Received: 30 March 2021

Received in revised form: 10 June 2021

Accepted: 19 June 2021

Keywords:
Hz. Aisha
Critical
Companios

ÖZ

Allah Rasûlü'nün verdiği eğitim ve öğretim sayesinde sahabe arasında eleştirel zihniyetin hayli canlı olduğu herkesin malumlarıdır. Bu zihniyetin en önde gelen siması hiç şüphesiz Hz. Âişe annemizdir. $\mathrm{O}$, keskin zekası ve muhakemesi, sahip olduğu öğrenme iştiyakı, gerçeği öğrenebilme adına yapmış olduğu sorma ve sorgulama yeteneği ile daha Hz. Peygamber zamanında bu sahada temayüz etmiştir. Tebliğimizde "istidrâk" kavramının kapsamı, sorulan soruya cevap verme, bir hususu idrak etmeye çalışma, itiraz etme, düzeltme, açıklama yapma ve nihayet eleştirme olmak üzere oldukça geniş tutulacaktır. Konuyu, vereceğimiz çeşitli örneklerle şu dört başlık altında inceleyeceğiz: Hz. Peygamber'in, Hz. Âişe'ye Yönelttiği İstidrâkler, Sahabenin Hz. Âişe'ye Yönelttiği İstidrâkler, Kadîm Alimlerin Hz. Âişe'ye Yönelttiği İstidrâkler, Çağdaş Alimlerin Hz. Âişe'ye Yönelttiği İstidrâkler.

\section{A B S TR AC T}

Thanks to the education and training given by the Prophet, it is known by everybody that the critical mindset is very lively among the Companions. Hz. Aisha is undoubtedly the most prominent figure of this mentality. With her sharp intelligence and judgment, her desire to learn, and her ability to ask and question the truth, she stood out in the time of the Prophet.We will examine the subject with the various examples we will give, under the following four headings: Istidraks that the Prophet directed to Hz. Aisha, Istidraqs directed by the Companions to Hz. Aisha, Istidraks directed to Hz. Aisha by the Ancient Scholars, Istidraqs directed by Contemporary Scholars to Hz. Aisha

\section{Giriş}

Allah Rasûlü'nün verdiği eğitim ve öğretim sayesinde sahabe arasında eleştirel zihniyetin hayli canlı olduğu herkesin malumlarıdır. Bu zihniyetin en önde gelen siması hiç şüphesiz Hz. Âişe annemizdir. O, keskin zekası ve muhakemesi, sahip olduğu öğrenme iştiyakı, gerçeği öğrenebilme adına yapmış olduğu sorma ve sorgulama yeteneği ile daha Hz. Peygamber zamanında bu sahada temayüz etmiştir. Onun Kur'an, Sünnet, Sîret ve Hadise olan vukufiyeti, aklı, muhakemesi ve ufku sayesinde birçok konuda gerek sahabe ve gerekse tabiun kuşağında ortaya çıkan birçok yanlış anlama, yorumlama ve hatalı aktarma karşısında derhal tashihler yapmasını sağlamıştır. Daha sonraları "istidrâk" diye nitelendirilen bu tür tashih ve tenkitleri, kendisinden sonrakiler için iyi bir çığır açmıştır. Nitekim ilerleyen asırlarda onun bu istidrâkleri, müstakil teliflere konu olmuştur. İlk telifi Ebû Mansûr el-Bağdâdî (ö. 489/1096) yapmış, Bedruddîn ez-Zerkeşî (ö. 794/1392) ise bu konuda en geniş çalışmaya imza atmıştır. Modern zamanlarda da Hz. Âişe'nin bu yönüne dair çeşitli çalışmalar yapılmıştır.

\footnotetext{
*Bu çalışma, 7 Aralık 2020 tarihinde Muş Alparslan Üniversitesi İslami İlimler Fakültesinde düzenlenen İslam Düşüncesinde Eleştiri Kültürü ve Tahammül Ahlâkı II (Klasik Dönem - M. VII. - XII. Yüzyıllar) Sempozyumunda sunulan bildirinin geliştirilmiş halidir.

** Sorumlu yazar/Corresponding author.

e-posta: berul65@ hotmail.com
} 
Aslında Hz. Âişe sadece eleştiren olmamış, hem kendi döneminde, hem de ilerleyen asırlarda çeşitli eleştirilere de maruz kalmıştır. Hz. Peygamber başta olmak üzere, farklı sahabilerden ve sonraki alimlerden onun bazı görüşlerine yönelik çok farklı eleştiriler ortaya çıkmıştır. İşte biz bu tebliğimizde daha çok Hz. Âişe'ye yöneltilen eleştirileri ele alacağız. Böylece, eleştirenin aynı zamanda eleştirilebileceğini de Hz. Âişe örneğiyle ortaya koymaya çalışacağız. Vereceğimiz birçok örnek, İslam düşüncesinde ne denli canlı bir eleştiri kültürü ve tahammül ahlakı olduğunu açık bir şekilde gösterecektir.

Konuya girmeden evvel hemen belirtmeliyiz ki, oldukça farklı konularda ortaya çıkan karşılıklı istidrâklerde, -ister sahabe olsun, isterse sonraki ulema olsun- kimin haklı ve daha isabetli olduğunu tespite çalışmayacağız. Zira ehlinin takdir edeceği üzere birçok deliller ileri sürülen ve sahabeden günümüze kadar ihtilaf edilen bir konuda yapılan tartışmaları incelemek ve hangi tarafin daha isabetli olduğuna karar vermek böyle bir tebliğin sınırlarını aşacaktır. $\mathrm{Bu}$ tebliğde bizim ortaya koymak istediğimiz husus, sahabe ve tabiine yönelttiği birçok istidrâkiyle meşhur olan Hz. Âişe'ye de çeşitli istidrâklerin yöneltildiğini gösterebilmek ve bu çerçevede bazı noktalara dikkat çekmektir. Tebliğimizde "istidrâk" kavramının kapsamı, sorulan soruya cevap verme, bir hususu idrak etmeye çalışma, itiraz etme, düzeltme, açıklama yapma ve nihayet eleştirme olmak üzere oldukça geniş tutulacaktır.

\section{Hz. Peygamber'in, Hz. Âişe'ye Yönelttiği İstidrâkler}

Burada ilk önce eş olarak birlikte geçirdiği sekiz yıl boyunca Hz. Âişe'nin, Peygamberimize sormuş olduğu çeşitli sorulara aldığı bazı cevapları zikredeceğiz. Bu soru ve cevaplarda Allah Rasûlü, bazen Hz. Âişe'nin belli bir konudaki yanlış anlayışını, bazen yanlış bir değerlendirmesini, bazen de ondaki ya bir zannı ya da yanlış bir bilgiyi tashih etmektedir.

Hz. Âișe'nin, bizzat Allah Resulü'nden ișittiği bir hadisi, konuyla ilgisi bulunan bir ayete aykırı gibi gördüğü için, işin mahiyetini kavrayabilmek kastıyla sorma ve sorgulama yöntemine başvurduğu görülebilmektedir. Nitekim İmam Buhârî (ö. 256/870), Kitâbu'l-İlm'de, “Bir Şey İşitip de Onu Anlayıncaya Kadar (Kaynağına) Başvuran Kimseler" başlığıyla açmış olduğu bir babda, İbn Ebî Müleyke'nin "Hz. Peygamber' in eşi Hz. Âişe, anlayamadığı bir şey işittiğinde, onu öğrenebilmek için o konuda (Hz. Peygamber'e) başvururdu." şeklindeki bir değerlendirmesini naklettikten sonra şu habere yer vermiştir:

Hz. Peygamber: "Her kim hesaba çekilirse, azap görür." buyurunca, Hz. Âişe: "Yüce Allah: '(Kimin kitabı sağdan verilirse), o, kolay bir hesaba çekilecektir.' buyurmuyor mu?" (İnşikâk, 84/7-8.) dedim, bunun üzerine o (s): "Bu, ancak (insanların teraziye) (İbn Hacer, 1407, c. I: 238) çıkarılışıdır; ama kimin hesabı tartışmalı geçerse, o helak olacaktır.” buyurdu.(Buhârî, 20153. İlm 35, I. 34; 65. Tefsîr 84/1, VI. 81; Müslim, 201651. Cennet 79-80, III. 2204-5; Tirmizî, 201546. Tefsîr 76, no: 3337, V. 435; Ahmed b. Hanbel, 1982, s. VI: 47, 91, 127, 206)
Bu haber, Hz. Âişe'nin işittiği bir hadisin mânâsını anlamaya, Sünnet'i, Kitap ile karşılaştırmaya, künhünü kavrayamadığ 1 hususta hemen soru sormaya olan gayretini göstermektedir. Bunu Rasûlullâh'ın (s) huzurunda yapması, bizzat onun izah ve tashihine başvurması, bilgisini arttırmakta ve fikrini geliştirmekteydi.(İbn Hacer, 1407, c. I: 238; İdlîbî, 2013, s. 109)

Hz. Âişe şöyle anlatmaktadır: "Bir gün süt amcam geldi ve yanıma girmek için izin istedi. Ben Rasûlullâh'a (s) sormadan ona izin vermedim. Rasûlullâh (s) geldi ve ona bu hususu sordum. O: "O senin amcandır, ona izin ver!" dedi. "Ey Allah'ın Rasûlü! Beni kadın emzirdi, erkek değil ki?" dedim. O: "O senin amcandır, yanına girsin!" dedi. Bu, hicab emri geldikten sonra idi. (Buradan anlaşıldı ki) Doğumdan dolayı haram (mahrem) olan, emmeden dolayı da haram (mahrem) olmaktadır."(Buhârî, 2015, s. 5239; Müslim, 2016, ss. 3575, 3579; Mâlik, 1985, s. 1276; Ahmed b. Hanbel, 1982, ss. 24054, 25823)

Diğer taraftan yine Hz. Âişe'nin rivayetine göre birgün Hz. Peygamber, onun yanında tanımadığı birisinin oturduğunu görünce, bundan dolayı yüzünün rengi değişmiş, bundan hoşlanmadığı anlaşılınca, Hz. Âişe onun, sütkardeşi olduğunu söylemişti. Bunun üzerine Allah Rasûlü: "Kardeşlerinizin kim olduğuna iyi bakın! Emme (ile oluşan haramlılık) ancak (bebek iken emzirilen) açlık sebebiyledir!'(Buhârî, 201567. Nikâh, 22, VI. 125-6; Müslim, 2016 Radâ', 32, II. 1078) diyerek bu konuda onu uyarmıştır.

Hz. Âişe'nin anlattığına göre bir gün Ümmü Sünbüle Rasûlullâh'a (s) süt getirmiş ama onu bulamamıştı. Hz. Âişe ona, Rasûlullâh'ın (s) bedevilerin yemeklerini yemekten nehyettiğini söyledi. O esnada Rasûlullâh ve Ebû Bekr çıkageldi. Hz. Peygamber: "Ey Ümmü Sünbüle, yanındaki nedir?" diye sordu. O: "Ey Allah'ın Rasûlü, size hediye etmek üzere getirdiğim süttür." Dedi. Rasûlullâh'ın talebi üzerine hem Ebû Bekr, hem de kendisi o sütten içti. Hz. Âişe: "Ey Allah'ın Rasûlü, bana senin bedevilerin yemeklerini yemediğim haber verilmişti?” dedi. Bunun üzerine $\mathrm{Hz}$. Peygamber: "Ey Âişe! Onlar bedevi değil, onlar bizim çöldeki ailemiz, biz de onların şehirdeki ailesiyiz. Onlar, davet edildiklerinde, derhal icabet ederler. Onlar bedevi değillerdir." diye cevap verdi.(Ahmed b. Hanbel, 1982, c. VI: 133)

Hz. Âişe'nin rivayet ettiğine göre Hz. Peygamber'in 'Kim Allah'a kavuşmayı isterse, Allah da ona kavuşmayı ister. Kim de Allah'a kavuşmayı istemezse, Allah da ona kavuşmayı istemez" dediğini işitince ben: "Ey Allah'ın Rasûlü! Hepimiz ölümü istemeyiz?!” dedim. Bunun üzerine o: "Durum böyle değildir. Mümin, Allah'ın rahmeti, rızası ve cenneti ile müjdelendiğinde Allah'a kavuşmayı ister, Allah da ona kavuşmayı ister. Kafir ise Allah'ın azabı ve gazabı ile müjdelendiğinde, o Allah'a kavuşmayı istemez, Allah da ona kavuşmayı istemez" buyurdu' ${ }^{1}$ (Tirmizî, 2015, s. 1067).

Rasûlullâh (s) "İnsanlar, yalın ayak, çıplak ve sünnetsiz olarak haşrolunacaktır” buyurunca ben: “Ey Allah'ın Rasûlü, erkekler ve kadınlar birbirlerine bakarlar?!" diye sorunca o: "O gün durum, bununla ilgilenmekten çok daha çetindir!" buyurdu (Müslim, 201651. Cenne 56, III. 2194; Ahmed b.

${ }^{1}$ Bu konudaki farklı rivayetler için (Bkz. Zerkeşi, 2020, ss. 89-90). 
Hanbel, 1982, c. VI: 53, 90; İbn Mâce, 201037, Zühd 33 h.no: 4229, II: 1429; Buhârî, 201560, Enbiya, 8, 48, IV:110, 142).

Hz. Âişe'nin anlattığına göre Ensar çocuklarından birinin cenazesi Rasûlullâh'ın (s) huzuruna getirildi ve cenaze namazını kıldı. Ben dedim ki: "Ne mutlu ona! O, cennet serçelerinden bir serçedir. Her hangi bir kötülük yapmadığ 1 gibi, kendisine bir kötülük de ulaşmamıștır!” Bunun üzerine o (s) şöyle dedi: "Başka birşey deseydin ya ey Âişe! Zira Yüce Allah, cenneti yarattığı gibi, cennet halkını da yaratmış, onları tâ babalarının sulbünde yaratmıştır. Aynı şekilde cehennemi yarattığı gibi, cehennem halkını da yaratmış, onları da tâ babalarının sulbünde yaratmıştır." (Ahmed b. Hanbel, 1982, c. VI: 41 h.no: 24132; Nesâi, 2010, s. 1949)

Hz. Âişe'nin anlattığına göre Allah Rasûlü (s) tam bir ay hanımlarının yanına girmemeye yemin etmişti. Bu şekilde 29 gün kaldı ve ilk bana geldi. Ona: "Sen bir ay girmeyeceğim diye yemin etmemiş miydin?" dedim. Hz. Peygamber: "Ay, 29 gündür" buyurdu.(Ahmed b. Hanbel, 1982, c. VI: 33 h.no: 24050)

Allah Rasûlü'nün, eşi Âişe'ye verdiği mezkur cevaplar, yönelttiği bu düzeltmeler, Hz. Âişe'nin istidrâkleri gibi, herhangi bir hadisin yanlış alınması veya yanlış nakledilmesi nevinden değildir. Aksine bu istidrâklerden bir kısmı, ondaki yanlış bir bilgiyi veya yanlış kanaati düzeltmeye, onda gördüğü bazı endişeleri gidermeye ve bunları tashih etmeye yöneliktir. Verilen bu örneklerden anlaşılmaktadır ki, Hz. Âişe serdettiği bu görüş ve kanaatlerinde isabetli değildir ve Allah Rasûlü müdahale ederek onun yanılgılarını ve yanlış anlamalarını düzeltmiştir. O (s) bu tür tashihler yaparken, aslında onun şahsında ümmetine de birtakım ahlaki dersler vermiştir.

\section{Sahabenin Hz. Âişe'ye Yönelttiği Eleștiriler}

F1khı, muhakeme gücü ve zekâsı ile ün yapmış olan Hz. Âişe'nin, bazı noktalarda görüşünde tek kaldığı görülebilmektedir. $\mathrm{Bu}$ nedenle sahabeden bazıları $\mathrm{Hz}$. Âişe'nin bu kabil bazı görüşlerine veya fetvalarına katılmamışlardır. İşte bu kısımda sahabenin Hz. Âişe'ye yönelttikleri bazı istidrâklerden örnekler verilecektir.

Ümmehâtu'l-müminîn, yetişkin bir erkeğin (radâu'l-kebîr) emmek suretiyle süt bağı oluşturması ile ilgili Hz. Âişe'ye olan muhalefetleri bunun için güzel bir örnektir. Sahabeden Sehle bint Suheyl'in kocası Ebû Huzeyfe b. Utbe b. Rabîa, Sâlim'i evlatlık edinmiş, sonra onu kardeşinin kızıyla evlendirmişti. Ancak evlatlık edinmeyi kaldıran ayetler inince, (Ahzâb, 33/4-6) Sehle Hz. Peygamber'e gelerek “Biz Sâlim'i bir evlat gibi görüyorduk ve bizim tek bir evimiz/odamız olduğundan, ben ev içi kıyafeti içerisindeyken bile o yanıma giriyordu, onun durumu ne olacak?" diye sordu. Hz. Peygamber ona: "Onu beş defa emzir ki, süt ile haramlık oluşsun!" buyurdu. Artık bundan sonra Sehle onu süt oğlu gibi görmeye başladı. Hz. Âişe, yanına girmelerini istediği adamlar için bununla amel ediyor, hatta kızkardeşi Ümmü Gülsüm ve kardeşinin kızlarına, yanlarına almak istedikleri erkekleri aynı şekilde emzirmelerini emrediyordu.

Hâlbuki Hz. Peygamber'in diğer hanımları, bu şekilde emzirme yoluyla insanlardan hiçbir kimsenin yanlarına giremeyeceği konusunda direttiler ve şöyle dediler: "Hayır
Vallâhi! Biz Rasûlullâh'ın Sâlim'i emzirmesi konusunda Sehle'ye emrettiği uygulamanın, sadece Sâlim için verilmiş bir ruhsat olarak görüyoruz. Hayır, vallâhi bu şekilde bir emzirme yoluyla bizim yanımıza kimse giremez."(Mâlik, 1985, c. Radâ' 12, I: 605-606; Abdurrezâk, 1403, c. VII. 459460, h.no: 13886; Müslim, 2016, c. Radâ' 31, II: 1078; Nesâî, 2010, c. Nikâh 53, VI: 106.) Bazı rivayetlerde ise, aralarında Ümmü Seleme'nin de bulunduğu diğer eşler ihtimalli bir ifade ile "Bilemeyiz ki, belki bu yalnızca Sâlim'e has bir ruhsattır." demişlerdir.(Abdurrezâk, 1403, c. VII: 459, h.no: 13885; Ebû Dâvûd, 2009, s. Nikâh, 10, h.no: 2061, II: 549-551) Yine kimi rivayetlerden Sehle'nin bu girişiminin, Sâlim'in, yanına girip çıkmasından dolayı Ebû Huzeyfe'nin hissettiği rahatsızlığı gidermeye yönelik olduğu ve böyle bir çözüm yoluyla başarılı olduğu da anlaşılmaktadır (Müslim, 2016, c. Radâ' 26-30, II: 10761078; Nesâ̂i, 2010, c. Nikâh 53, VI: 104-106).

Başka bir rivayette Ümmü Seleme, Âişe'nin yanına giren büluğ çağına yaklaşmış bir oğlanın kendi yanına girmesini istemediğini söyleyince Hz. Âişe “Allah Resulü'nde senin için örnek yok mu?" diyerek Sâlim'in durumunu hatırlatmıştır (Müslim, 2016, c. Radâ' 20-30, II: 1077-1078).

Anlaşılan o ki, Hz. Peygamber'in diğer eşleri Sâlim'in emmesini yalnızca ona has görürken, Hz. Âişe bunu herkes için amel edilebilir nitelikte bir yöntem olarak görmektedir. Her ne kadar kaynaklarımızda, Hz. Âişe'nin bu kanaatte olduğu rivayet edilmekte ise de, doğrusu biz fikhî yönü ile meşhur olan Hz. Âişe'nin bu meselede böyle bir görüşü benimsemiş, onunla amel etmiş ve yeğenlerine de önermiş olabileceğinden emin değiliz. Onun genel fikhî görüşleri ve tenkitçi zihniyeti sebebiyle böyle bir kanaata sahip olması uzak bir ihtimal olarak gözükmektedir. Nitekim Sâlim'in durumunu muhtasar olarak nakleden Buhârî, Hz. Âişe'nin kanaatine yer vermemiştir.(Buhârî, 2015, c. Nikâh, 15, VI: 122) Yine Hz. Âişe'nin bu görüşü benimsediği, kendi rivayetlerinde dile getirilmezken;(Müslim, 2016, c. Radâ' 26-28, II: 1076-1077; Nesâî, 2010, c. Nikâh 53, VI: 104-105; Ahmed b. Hanbel, 1982, s. VI: 39) Urve, (Mâlik, 1985 Radâ', 12, II. 605-6) Atâ'(Abdurrezâk, 1403, c. VII: 458, h.no: 13883) ve Zuhrî tarafindan nakledilmektedir. Hatta Zuhrî, Hz. Âişe'nin ölünceye dek bu doğrultuda fetva vermeye devam ettiğini söylemektedir (Abdurrezâk, 1403, c. VII: 459, h. no: 13885, VII: 460, no: 13886). Oysa Hz. Âişe'nin kendi rivayetine göre Hz. Peygamber, onun yanındaki tanımadığı kimsenin onun sütkardeşi olduğunu öğrendiğinde: "Kardeşlerinizin kim olduğuna iyi bakın! Emişme ancak (bebeklik dönemindeki) açliktan dolayıdır!'(Buhârî, 2015, c. Nikâh, 21, VI: 125-126; Müslim, 2016, c. Radâ', 32, II: 1078) diyerek bu konuda onu uyarmıştır. Dahası sütkardeşliğin, iki yıllık süt emme döneminde olacağına, sütten ayrıldıktan sonraki yıllarda böyle bir kardeşliğin tahakkuk etmeyeceğine dair hem Hz. Peygamberden, hem de sahabeden birçok rivayet gelmiştir.(Abdurrezâk, 1403, c. VII: 464-5, h.no: 1389713906; Mâlik, 1985, c. Radâ' 4, 6, 14, I. 602-603, 607) 
Kur'an'a $^{2}$ ve Sünnet'e vâkıf olan Hz. Âişe'nin, sütkardeşliğini doğuracak emme döneminden habersiz olduğu düşünülemez. Nitekim o, İbn Ömer'in, oğlu Sâlim'i k1z kardeşi Ümmü Gülsüm'e emmesi için gönderdiğinde Sâlim henüz süt emen bir bebekti.(Mâlik, 1985 Radâ' 7, I. 603) Keza Hz. Hafsa, Âsım b. Abdullâh b. Sa'd'ı kızkardeşi Fâtıma'ya gönderdiğinde, Âsım henüz süt emen bir bebek olup, bunu yaptıktan sonra onun yanına girip çıkmaya başlamıştır.(Mâlik, 1985 Radâ' 8, I. 603) Bu rivayetler de gösteriyor ki, sahabede yaygın olan tatbikat, çocukların henüz bebek iken emzirilmeleri șeklindedir.

Nitekim Subkî (ö. 756/1355), Muhammed b. Halîl elEndülüsî'nin $-\mathrm{Hz}$. Âişe'nin bu doğrultuda fetva verdiği sahih olarak rivayetlerde gelse de- bu konuda tavakkuf ettiğini ve Hz. Âişe'nin bu şekilde (yetişkinleri) emzirme yoluyla yanına hiçbir yabancıyı almasının vuku bulmadığını yazdığını nakletmektedir (İbn Hacer, 1407, c. IX: 53).

Sonuç olarak biz, Hz. Âişe'nin böyle bir görüşü benimsemesini, bu doğrultuda fetva vermesini -rivayetlere rağmen- uzak bir ihtimal olarak görüyoruz. Şayet bu rivayetleri sahih olarak kabul edersek, bunun onun kişisel bir kanaatinden $^{3}$ öteye geçemeyeceğini söyleyebiliriz. ${ }^{4}$

İkinci örneğimiz ise, Hz. Peygamber'in ikindi namazından sonra kıldığ 1 nafile namazla ilgilidir. Bu konuda Hz. Âișe'ye hem Ümmü Seleme'den, hem de Zeyd b. Sabit'ten gelen istidrâkler bulunmaktadır.

Mervan b. el-Hakem, Abdullah b. ez-Zübeyr'e İkindi namazından sonra kıldığı iki rekâtı nereden aldığını sordu. O da, kendisine Ebû Hureyre'nin Âişe'den haber verdiğini söyledi. Mervan durumu öğrenmek için Hz. Âişe'ye birini gönderdi. O: "Bunu bana Ümmü Seleme haber verdi" dedi. Bu defa Ümmü Seleme'ye müracaat edildiğinde ise, o: “Allah, Âişe'ye mağfiret eylesin. Benim haberimi farklı anlamış. Allah Rasûlü (s) Öğle namazını kıldırmış ve benim günümde bana gelmişti. Hemen hafif iki rekât namaz kıldı. Ben: "Bu iki rekât namaz nedir ey Allah'ın Rasûlü? Yoksa bu namazı kılmakla mı emrolundun?" diye sorunca o: "Hayır, o iki rekât, benim Öğle namazından sonra kılmakta olduğum namazdır. Bugün mescitte yaptığım mal taksimi beni meşgul etti ve o iki rekâtı kılamadan İkindi oluverdi. Ben de kılamadığım o iki rekâtı terk etmek istemedim" dedi. Zaten ben, Hz. Peygamber'in o iki rekâtı ne daha önce, ne de daha sonra kıldığını görmemiştim."5(Ahmed b. Hanbel, 1982, c. VI: 299-300) Diğer bir rivayette ise Ümmü Seleme “Allah, Âişe'ye rahmet eylesin! Ben ona Rasûlüllah'ın bu iki rekâtı yasakladığını haber vermedim mi?!" demiştir (Ahmed b. Hanbel, 1982, c. VI: 303; İbn Ebî Şeybe, 2006, s. II: 133, h.no: 7346).

Hz. Âişe'den gelen başka bir rivayette ise, Hz. Peygamber'in onun yanında da ikindiden sonra iki rekât namazı kıldığını Zubeyr ailesine haber vermiş, onlar da bu namazı kılmaya devam etmişlerdi. Bunu duyan Zeyd b. Sâbit, Hz. Âişe'ye şu eleştiriyi yöneltmiştir: “Allah, Âişe’ye mağfiret etsin. Biz

${ }^{2}$ Bakara, 2/233'te “Anneler, çocuklarını emzirmeyi tamamlamak isteyenler için tam iki yıl emzirirler.” buyurulmaktadır. Ayrıca bkz. Lokmân, 31/14; Ahkâf, 46/15.

${ }^{3} \mathrm{~Hz}$. Ali de yetişkinken tedavi amacıyla sütünü içtiği hanım ile evlenmek isteyen birisine "Evlenme!" diyerek nehyediyor (bkz. Abdurrezâk, 1403, s. VII: 461, h.no: 13888).

${ }^{4}$ Bu mesele ile ilgili geniş bilgi için (bkz. İbn Kayyim el-Cevziyye, 1994, c. V: 577-593).
Rasûlüllah'1 Âişe'den daha iyi biliyoruz. Bu, husus şöyle oldu: Öğleye doğru Hz. Peygamber'e bedevilerden bir grup geldi. Oturup ona sorular sordular o da onlara cevaplar verdi. Öğle namazını kıldırdı, sonrasında kıldığı iki rekatı kılamadan tekrar soru cevap faslı devam etti. Nihayet İkindi namazını kıldırdıktan sonra evine geçti ve Öğle sonrası namaz kılmadığını hatırlayarak İkindi namazından sonra o iki rekat namazı kıldı. Allah, Âişe'ye mağfiret etsin. Biz Rasûlüllah'1 Âişe'den daha iyi biliyoruz. Halbuki Rasûlüllah (s) ikindiden sonra namaz kılmayı yasaklamıştı (Ahmed b. Hanbel, 1982, c. V: 185).

$\mathrm{Bu}$ rivayetlerde Ümmü Seleme ile Zeyd b. Sâbit, ikindi namazı sonrasında Hz. Peygamber'in iki rekât namazı neden kıldığını çok iyi bilmektedirler. Hz. Âişe ise bu durumu göz ardı etmiş ve adeta diğer namazların ardından kıldığı nafileler gibi iki rekat nafile kıldığını zannederek Ümmü Seleme'den aldığı bilgiyi öylece nakletmiştir. Hz. Peygamber, söz konusu namazı Ümmü Seleme'nin gününde ve onun evinde kılmıştır. Ümmü Seleme'nin sorusu üzerine Hz. Peygamber durumu izah etmiştir. Olayın şahitlerinden birisi de Zeyd b. Sabit'tir ve o da bu namazın neden kılındığını net bir şekilde izah etmektedir.

Hz. Âişe'ye karşı oldukça ilginç bir istidrâk de Ebû Hureyre'den gelmektedir: Hâkim (ö. 405/1014), Mustedrek adlı eserinde rivayet etmiştir: Hz. Âişe, Ebû Hureyre'yi yanına çağırarak: "Ey Ebû Hureyre! Hz. Peygamber'den rivayet ettiğini işittiğimiz bu hadisler de nedir? Sen de, sadece bizim işittiklerimizi işittin, sadece bizim gördüklerimizi gördün?” diye sorunca Ebû Hureyre şöyle cevap verdi: "Ey annem! Ayna, sürme ve Rasûlüllah (s) için süslenmen, seni Rasûlüllah'tan (s.) alıkoyarken, vallahi, beni ondan alıkoyacak hiçbir meşguliyetim yoktu." "Hâkim enNisâbûrî, 1990, c. III: 509) Benzer bir haberi, Râmehurmuzî (ö. 360/970) ve İbn Sa'd (ö. 230/845) da eserlerinde nakletmişlerdir (Râmehurmûzî, 1971, s. 555 no:747; İbn Sa'd, 2002, c. II: 364).

Bu rivayette hem Hz. Âişe'nin Ebû Hureyre'ye itirazı, hem de Ebû Hureyre'nin ona vermiş olduğu cevap, genel olarak hadisleri işitme ve doğru nakletme ile ilgilidir. Kaynaklarımızda daha çok Hz. Âișe'nin Ebû Hureyre'ye yönelttiği istidrâkler rivayet edilmektedir. Zikrettiğimiz bu rivayet ise, neredeyse Ebû Hureyre'nin çok hadis rivayet edişinin farklı tarzda bir izahıdır. Buna göre o, Hz. Peygamber'i genelde evinde izleme imkanı bulabilen $\mathrm{Hz}$. Âişe'nin hilafina, bir erkek olması hasebiyle Rasul-i Ekrem'i daha fazla izleyebilmiş ve böylece daha fazla bilgi sahibi olmuştur.

\section{Kadîm Âlimlerin Hz. Âișe'ye Yönelttiği Eleştiriler}

Hz. Âişe'nin bazı istidrâkleri, çeşitli âlimlerce de tasvip edilmemiş, onun istidrâklerine karşı istidrâkler yapılmıştır. Farklı gerekçelerle onlar, Hz. Âişe'nin görüşlerine katılmayarak onun yanıldığını iddia etmişlerdir. Bu

\footnotetext{
${ }^{5}$ Abdurrezzâk ise o "Bir defadan başka Resulullah'ın aslâ ikindiden sonra namaz kıldığını görmedim...” der (Abdurrezâk, 1403, c. II: 432, h.no: 3970).

${ }^{6}$ Hâkim: "Bu, isnadı sahih bir hadis olup, Buhârî ve Muslim onu rivayet etmemişlerdir." demiştir. Zehebî (ö. 748/1348) de bunu onaylamıştır. Zehebî'nin naklettiği bir haberde ise, Hz. Âişe cevaben "Belki de öyledir.” demiştir (Zehebî, 1985, c. II: 604).
} 
çerçevede tespit edebildiğimiz bazı örnekleri şöyle siralayabiliriz:

Buhârî (ö. 256/870), İbn Ömer'in şöyle dediğini rivayet etmiştir: 'Hz. Peygamber Bedir'de (müşrik ölülerin topluca gömüldükleri) çukurun başına varıp 'Rabbinizin size vadettiği şeyin gerçek olduğunu gördünüz mü?’ dedikten sonra 'Onlar şimdi benim dediklerimi işitiyorlar' buyurdu." Bu hâdise Hz. Âişe'ye haber verilince o: "Hz. Peygamber, ancak 'Onlar şimdi benim söylediklerimin hak olduğunu biliyorlar' demiştir” dedi (Buhârî, 2015, c. Cenâiz 87, II. 101; Meğâzî 8, 12, V. 9, 21).

$\mathrm{Bu}$ konuda cumhur $\mathrm{Hz}$. Âişe'ye muhalefet etmiş ve başkalarının rivayetleriyle de uyumlu olduğu için İbn Ömer'in rivayetini kabul etmişlerdir. $\mathrm{Bu}$ alimler, $\mathrm{Hz}$. Âişe'nin Buharî, Müslim ve başkaları tarafından 'Siz benim dediklerimi onlardan daha iyi işitemezsiniz.' şeklindeki hadisi rivayet edenlere yöneltmiş olduğu istidrâkinde isabetli olmadığını açıklamışlardır. Onun, ölülerin işitmesine karşı çıkması, tıpkı bilgisi olmadığı halde karşı çıktığı diğer meseleler türündendir. $\mathrm{O}$, bu konuda da ictihad etmiștir ve ictihad eden de isabetli olabildiği gibi yanılabilir de." (Şimâlî, 1997, ss. 232-233)

Anlaşıldığı kadarıyla Hz. Peygamber' in 'Onlar şimdi benim söylediklerimin hak olduğunu mutlaka biliyorlar' söylediğine dair bir ifade Bedir Vakasına tanıklık eden ve hadisi doğrudan Hz. Peygamber'in lafizlarından işiten sahabilerin rivayetlerinde sabit olmamıştır. Bu cümle, ancak Hz. Âişe'nin rivayetindendir. Görünen o ki, o bunu $\mathrm{Hz}$. Peygamber'in söylediğinden kendi ictihadıyla anladığına dayanarak söylemiştir. Bundan dolayı da (ilgili) Kur'an ayetini delil getirmiş, bunu doğrudan Hz. Peygamberden işittiğini de zikretmemiştir. $\mathrm{O}$ hadisi rivayet eden sahabînin işitmede hata ettiğini zannetmiş ve ona itiraz etmiştir. Oysa onun kaçırdığı bir husus var ki o da, aynı hadisi Ebû Talha, Hz. Ömer, İbn Mes'ûd ve Abdullah b. Sîdân da rivayet etmişler ve hepsi de Bedir'de bulunmuşlardır (Şimâlî, 1999, s. 91).

Suheylî (ö. 583/1187), er-Ravdu'l-unf adlı eserinde şöyle demektedir: "Hz. Âişe orada bulunmamıştı. Başkaları ise orada bulundukları için Hz. Peygamber'in lafzını daha iyi bellemişlerdir. Nitekim onlar ona 'Ey Allah'ın Resulü! Kokmuş kokuşmuş bir ceset topluluğuna mı sesleniyorsunuz?' deyince o (s) 'Siz benim dediklerimi onlardan daha iyi işitemezsiniz.' buyurdu."

Onların bu durumu bilmeleri caiz olunca, işitmeleri de caizdir. Bu, ya ruhun cesede dönmesiyle veya soru esnasinda kısmen dönmesiyle (normal) kulaklarıyla işitmek suretiyle gerçekleşir ki bu, Ehl-i Sünnet'in görüşüdür. Yahut sorunun ruha yöneltildiğini söyleyenlere göre bu ruh, kısmen veya tamamen cesede dönmeksizin kalp veya ruh kulağıyla gerçekleşir. Suheylî şöyle der: 'Hz. Âişe'nin 'Sen kabirlerdekilere işittirebilecek değilsin!' (Fâtır, 35/22.) ayetini delil getirdiği rivayet edilmiştir. Oysa bu ayet, tıpkı 'Sağıra sen mi duyuracaksın, âmâya sen mi yol göstereceksin?' (Zuhruf, 43/40) ayeti gibidir. Yani hidayet eden, kalp kulaklarına ögütü ulaştıran, onları buna muvaffak kılan Allah’tır, sen değilsin. Burada Allah kafirleri ölülere ve sağırlara benzetmek suretiyle onları ölü ve sağır diye nitelendirmiştir. Ama dilediği zaman hakikati onlara duyuracak olan Allah'tır, Peygamber ya da başka bir kimse değildir. Dolayısıyla bu ayetin Hz. Âişe'nin görüşüyle iki cihetten ilgisi yoktur:

1. Bu ayet, sadece kafirlerin imana daveti hakkında inmiştir.

2. Bu ayet, onlara duyuranın Hz. Peygamber olduğunu nefyetmiştir. Ve Allah doğru söylemiştir. Onlara dilerse, sadece kendisi duyurabilir (Süheylî, t.y., c. V: 174-176).

Hz. Âişe'nin bu görüşüne benzer şekilde itiraz eden alimler arasında Beyhakî (ö. 458/1066), İsmailî (ö. 371/981), Zehebî (ö. 748/1348), İbn Receb el-Hanbelî, İbn Teymiye (ö. 728/1328) ve İbn Hacer (ö. 852/1448) de bulunmaktadır (İbn Teymiyye, 2004, c. IV: 299; İbn Hacer, 1407, c. VII: 213, 443).

Burada şunu da belirtmeliyiz ki, Hz. Âişe'nin istidrâklerinde gayet isabetli olduğu hâlde, onun hatalı olduğunu söyleyen ve böylece kendileri hataya düşen âlimlerimiz de bulunmaktadır.

Gerek geçmişte ve gerekse günümüzde bazı ilim adamları, Hz. Âişe'nin bazı itiraz ve eleştirilerinde bu şekilde kişisel yorumuyla te'vil cihetine gittiğini söylemişlerdir. Mesela, Ebû Hureyre'nin rivayet ettiği “Sizden birinizin, karnını irin ve kan ile doldurması, şiirle doldurmasından daha hayırlıdır.” hadisini, Hz. Âişe: “O, hadisi (iyi) belleyememiş, Rasûlüllah (s.) ancak: 'Sizden birinizin, karnını irin ve kan ile doldurması, benim hicvedildiğim bir şiirle doldurmasından daha hayırlıdır.' demiştir." şeklinde düzeltmiştir. İbn Vehb (ö. 197/812), Ebû Ubeyd (ö. 224/838) ve Suheylî (ö. 583/1187) Hz. Âişe'nin bu hadisi Hz. Peygamber'in hicvedildiği şiirler hakkında olduğu şeklinde te'vil ettiğini söylemişlerdir (Görmez, 2000, s. 174).

Suheylî (ö. 583/1187) er-Ravdu'l-unf adlı eserinde şöyle der: İbn Vehb (ö. 197/812) el-Câmi' adlı eserinde şunu zikretmektedir: "Hz. Âişe, bu hadisi, Hz. Peygamber'in hicvedildiği şiirler hakkında olduğu şeklinde te'vil etmiş ve bunu bütün şiirlere teşmil eden kimsenin kanaatine karşı çıkmıştır."

Suheylî der ki: “Hz. Âişe'nin rivayetine dayanarak bu şekilde söylediğimiz zaman, geriye sadece 'karnını şiirle doldurması' kusuru kalmıştır. Fakat anlatım ya da, lügatta istişhâd bakımından yapılan az (şiir) rivayeti ise, bu nehyin kapsamına girmez." Yine o dedi ki: "Ebû Ubeyd (ö. 224/838), hadisin Hz. Peygamber'in hicvedildiği şiirler hakkında olduğu şeklinde te'vil edenlere karşı çıkmakta ve şöyle demektedir: "Bu şekilde hicveden yarım beytin dahi rivayeti haram iken, nasıl olur da, karnın kanla dolması ifadesiyle, bu tür şiirlerle dolmasından söz edilebilir?!” (Ebû Ubeyd, 1964, c. I: 36-37).

Suheylî dedi ki: “Ama Hz. Âişe ondan daha iyi bilir. Çünkü hikâye (anlatım) cihetiyle bu şiirlerden bir, iki veya daha fazla beyit, Rasûlüllah'in (s.) zemmedildiği nesir söz gibidir ${ }^{7}$ ve aralarında fark yoktur." Suheylî, böylece kafirlerin Hz.

\footnotetext{
${ }^{7}$ Şiirin, diğer sözler gibi olup, iyisinin iyi, kötüsünün de kötü olduğunu ifade eden bazı zayıf merfû' rivayetler için bkz. (Dârekutnî, 1966, c. IV: 155$156)$.
} 
Peygamber'i hicvettiği bazı şiirleri zikrinden dolayı İbn İshâk'1 mazur görmüştür (Süheylî, t.y., c. V: 73-74).

Zerkeşî’ye (ö. 794/1392) göre ise “Doğru olan, az olsun, çok olsun Hz. Peygamber'in hicvedildiği şeylerin rivayetinin haram kılınmasıdır. Belki de hadis, (hafızasını) böylesi şiirlerle dolduranlara karşı çıkmaktadır. $\mathrm{Bu}$ durumda (hicveden) az şiirin zemmedilmediği anlamı da çıkartılamaz. Nitekim şiirin çoğundaki mahzur, azında da aynen mevcuttur. Dolayısıyla Hz. Âişe'nin te'vili inşaallah doğrudur ve Ebû Ubeyd ile Suheylî'nin anladıkları uygun değildir." (Zerkeşi, 2020, ss. 222-225).

Başka bir misal de, Hz. Âişe'nin, ev, kadın ve atta uğursuzluk olduğunu bildiren Ebû Hureyre'nin rivayet ettiği hadise getirdiği şu düzeltmelerin eleştirilmesidir:

a. "Ebû Hureyre iyi ezberlememiş, o girdiğinde Rasûlüllah (s.) "Allah, Yahudileri kahretsin, şöyle derler: Uğursuzluk şu üç şeydedir; evde, kadında ve atta" buyurmuş ama o, hadisin başını işitememiş, sadece sonunu duymuştur."'(Tayâlisî, 1321, s. 215, h.no: 1537).

b. 'Kur'an'1 Ebû'l-Kâsım'a indiren (Allah'a) yemin ederim ki, o (s.) böyle söylemiyordu. Fakat Allah'ın Peygamberi şöyle buyurmuştu: 'Cahiliye insanları şöyle derlerdi: Uğursuzluk; kadında, evde ve attadır'.”(Ahmed b. Hanbel, 1982, c. VI: 246, 150, 240).

"Bahis konusu hadis, ileriki asırlarda dahi pek çok ihtilaf ve te'villere mevzu teşkil etmiştir. Hz. Âişe'nin Ebû Hureyre'ye müteveccih bu reddiyesini kabul etmeyenler arasında, mesela İbnu'l-Cevzî (ö. 597/1200), Kastalânî (ö. 923/1517) ve İbn Hacer (ö. 852/1448) vardır. Dayandıkları nokta, adı geçen hadisin isnadlar bakımından sağlam, başka sahabeden de aynı şekilde rivayet ediliyor olmasıdır. Meseleyi Kur'an zihniyetiyle mütalaa edenler ise, Hz. Âişe'nin görüşüne katıliyorlar..." (Mehmed Said, 1971, ss. 64-65).

Hz. Âişe'nin, "Uğursuzluk üç şeydedir." rivayetine karş1 çıkmasını, Hattâbî (ö. 388/998) söz konusu hadisleri te’vil ederek uzlaştırmaya çalışmış; İbnu'l-Cevzî (ö. 597/1200) ise onu itimat edilmez bir itiraz olarak değerlendirmiştir. Ancak gerek Hattâbî'nin ilgili haberi te'vil yoluyla kurtarmaya çalışması, gerekse İbnu'l-Cevzî'nin sırf güvenilir bir cemaat tarafından rivayet edildiği gerekçesiyle bu konuda Hz. Âişe'ye karşı çıkması da ayrıca eleştirilmiştir (Görmez, 2000, ss. 174-175).

Cahiliyede mevcut olan bâtıl inançları ve hurafeleri her vesile ile kaldırmaya çalışan Hz. Peygamber'in, sayılan bu üç hususta uğursuzluk olduğunu söylemesi mümkün olmadığı için, varlığını rivayet eden sahabilerin yanlış veya eksik işittikleri ya da sehven yanlış naklettikleri gibi bir ihtimal ortaya çıkmaktadır.

Aslında bu konuda çeşitli sahabilerden içerikleri birbirinden farklı birçok rivayet gelmektedir ${ }^{8}$ ve bu durum söz konusu rivayette, yorum kargaşası yaşandığını göstermektedir. Zira Hz. Peygamber'in bütün bu birbiriyle çelişkili ifadeleri söylemesini kabul etmek mümkün değildir. Hz. Âişe'nin

${ }^{8}$ Farklı rivayetler için (bkz. Zerkeşi, 2020, ss. 207-211) Bu konuda şu makaleye bakılabilir: (Sağlam, 2017, ss. 81-108).

9 Tirmizî bu hadis için "hasen-garîb" demiştir (Hâkim en-Nisâbûrî, 1990, c. I: 65).

${ }^{10} \mathrm{~Hz}$. Âișe'nin bu rivayeti ve görüșü ile ilgili eleștirilerin bulunduğu kısımda bu veya bu mealde bir ifade bulamadık. İbn Abbâs'ın sahabe içerisindeki rivayeti de muhtemelen böyle bir yorumun neticesi olabilir. Şüphesiz, Hz. Âişe itirazında isabetlidir, ancak Hz. Peygamber'in ne söylediği konusunda, belirttiğimiz gibi diğer rivayetleri de dikkate almak zorundayı.

Bir başka örnek de Hz. Peygamber'in, Rabbini gördüğüne dair İbn Abbas'dan gelen rivayetlere (Tirmizî, 2015, c. Tefsîr 54, h.no: 3279, V: 395) ${ }^{9}$ Hz. Âişe'nin yaptığı itirazlarına İbn Huzeyme'nin (ö. 311/923) yönelttiği eleştirileridir. Hz. Âişe bu meyandaki rivayetlere şu şekilde karşı çıkmıştır:

"Her kim Muhammed'in, Rabbini gördüğünü iddia ederse, büyük bir laf etmiş demektir. Ama o, Cebrail'i (a.s.) kendi sureti ve yaratılışında ufuğu kaplamış olarak görmüştür.'(Buhârî, 2015, c. Bed'u'l-halk 7, IV: 83; Tefsîr 53,1, VI: 50; Müslim, 2016, c. Îmân 287, I: 159). "Her kim 'Muhammed (s.) Rabbini gördü.' diye iddia ederse, Allah'a büyük bir iftira atmış olur." dedi. Mesrûk: "Ey müminlerin annesi! Acele etme ve beni dinle! Allah (c.c.) 'Andolsun (Muhammed) onu apaçık ufukta görmüştür.' (Tekvîr, 81/23) 'Andolsun (Muhammed) onu bir kez daha inerken görmüştür. ' (Necm, 53/13) buyurmuyor mu?” dedim. Bunun üzerine o, şöyle cevap verdi: "Bu ümmet içerisinde bunu Rasûlüllah'a (s.) ilk soran ben oldum ve o şöyle buyurdu: 'O, ancak Cebrail idi, bu iki kerenin dışında onu yaratıldığı surette görmedim. Onu, semadan inerken bütün büyüklüğüyle yer ile gök arasını kaplamış olarak gördüm." Hz. Âişe devamla: "Sen Allah'ın (c.c.) şöyle buyurduğunu işitmedin mi?!: 'Gözler O’nu görmez, O gözleri görür. $O$ latîf ve her şeyden haberdardır.' (En'âm, 6/103)Yine sen Allah'ın (c.c.) şöyle buyurduğunu işitmedin mi?!: 'Allah, bir insanla (karşıllkll) konuşmaz. Ancak vahiyle yahut perde arkasından konuşur yahut bir elçi gönderip izniyle dilediğini vahyeder. O, yücedir, hakîmdir'.” (42. Şûrâ, 51) (Hadis için bkz. Müslim, 2016, c. Îmân 287, I: 159; Ahmed b. Hanbel, 1982, c. VI: 49; Tirmizî, 2015, c. Tefsîr 7, h.no: 3068, V: 262-3).

Zerkeş̂’’nin naklettiğine göre İbn Huzeyme, Kitâbu't-tevhîd adlı eserinde Hz. Âişe'nin bu eleştirilerine: "O (s.) Hz. Âişe'ye ancak aklının alacağı kadar konuşmuştur.”(İbn Huzeyme, 1988, c. II: $556-563)^{10}$ diyerek onun hatalı olduğunu göstermeye çalışmaktadır. Ona göre Hz. Âişe'nin nefyi bir ilme (hadise) dayanıyor değildir. Hz. Âişe, Hz. Peygamber'den, Rabbini görmediğine dair bir şey nakletmemektedir. Kendisi bu hükme, sadece ayeti te'vil ederek varmıştır." demiştir (Zerkeşi, 2020, ss. 177-181).

İbn Huzeyme özetle bu itirazında, Ma'mer b. Râşid'in (ö. 153/770), "Bizim nezdimizde Âişe, İbn Abbâs'tan daha âlim değildir” dediğini, Hz. Âişe'nin yanlış duymuş olabileceğini, bunu da öfkeli bir zamanda ve güzelce rivayet edememiş olabileceğini, rü’yetin varlığını rivayet eden sahabilerin Allah'a iftira etmelerinin mümkün olamayacağını dile getirmiştir (İbn Huzeyme, 1988, c. II: 556-563).

Nevevî de (ö. 676/ 1278) bu konuda benzer değerlendirmelerde bulunmuştur. O şöyle demektedir: "Hz. Âişe: "Ben, Hz. Peygamber'in (s) "Ben Rabbimi görmedim" dediğini işittiğini haber vermiş değildir. $\mathrm{O}$, ancak Şûrâ Suresi

yüksek ilmî mevkii malum olmakla birlikte, kanaatimizce Hz. Âişe, Kur'an ve Sünnet bilgisini bizzat Hz. Peygamber'den alırken, İbn Abbâs ondan ancak birkaç hadisi duyabilmiştir. Dolayısıyla İbn Abbâs'a nispetle Hz. Âişe'nin, ilmi doğrudan kaynağından alması gibi oldukça önemli bir imtiyazı ve üstünlüğü vardır (İbn Huzeyme, 1988, c. II: 556563). 
51. Ayet ile En'am Suresi 103. Ayetleri tevil ederek bunu söylemiştir. İbn Abbas, başkasının nefyettiği bir şeyin var olduğunu (gördüğünü) söylemektedir ve var olduğunu söyleyenin görüşü, yok olduğunu söyleyenin görüşüne takdim edilir. Velhasıl İbn Abbas ve başkalarından gelen hadislere dayanan alimlerin çoğuna göre Rasûlullâh (s) İsra gecesi Rabbini, iki gözüyle görmüştür. Sonra, Hz. Âişe, Hz. Peygamber'in Rabbini görmediğini Rasûlullâh'dan (s) naklettiği bir hadisle söylemiyor. Şayet bildiği bir hadis olsaydı o bunu mutlaka söylerdi. O, ancak bazı ayetlerden çıkardığı hükme dayanmaktadır (Nevevî, 1392, c. III: 5-6).

İbn Abbas ile Hz. Âişe'den gelen birbirine zıt bu iki görüş daha sonra birçok alimi uğraştırmaya devam etmiş ve konu enine boyuna tartışılmıştır (Geniş değerlendirmeler için bkz. İbn Hacer, 1407, c. XIII. 434).

Hz. Âişe'ye yöneltilen bir başka eleştiri de, onun Huzeyfe b. el-Yemân tarafindan nakledilen Hz. Peygamber'in ayakta bevlettiğine dair rivayetlere(Buhârî, 2015, c. Vudû 60-62, I: 62; Müslim, 2016, c. Tahâre 73-74, I: 228) karşı çıkması hakkındadır. $\mathrm{Bu}$ konuda $\mathrm{Hz}$. Âişe: "Her kim size Rasûlüllah'ın (s.) ayakta bevlettiğini haber verirse, onu tasdik etmeyin. Zira Rasûlüllah (s.) ancak oturarak bevlediyordu."(Tirmizî, 2015, c. Tahâre 8, no: 12, I: 17; Nesâî, 2010, c. Tahâre 25, I: 26; İbn Mâce, 2010, c. Tahâre 14, h.no: 307, I: 112; Hâkim en-Nisâbûrî, 1990, c. I: 185) diyerek karşı çıkmıştır (Zerkeşi, 2020, ss. 269-273).

İbn Kuteybe (ö. 276/889) ve Hattâbî’ye (388/998) göre Rasûlullâh'dan (s) sabit olan mutad davranışı, onun oturarak bevl etmesi şeklindedir. Bu, tercih edilen ve güzel görülen adetlerdendir. Ama onun ayakta bevletmesi ise belli bir sebep veya zaruretten dolayı yapmış olduğu nadir bir davranıştır.(Hattâbî, t.y., c. I: 18-19; İbn Kuteybe, 1999, s. 62).

Zerkeşî gibi bazı âlimler ise, iki rivayetin arasını uzlaştırmışlardır. Çünkü Hz. Âişe'nin hadisindeki nefy, genellikle ve devamlı yapıldığını gösteren "kâne” sîgasıly varit olmuştur. Huzeyfe'nin hadisinde ise "kâne" yoktur. Bu ise, bir kere de olsa, bir fiilin kesin olarak yapıldığını gösterir. Burada kastolunan ise, Hz. Peygamber'in sürekli hâlidir ve Hz. Âişe, Huzeyfe'nin gördügünü görmemiştir. Dolayısıyla, “Ben Hz. Peygamber'i çömelerek bevlederken gördüm" diyerek karşı çıkışını, kendi görmesine dayandırmaktadır. Aynı şekilde, "ispatın, nefye takdimi" şeklindeki usûl kaidesince gördüğünü anlatan Huzeyfe hadisi, görmediğini rivayet eden $\mathrm{Hz}$. Âişe hadisine takdim edilir (Zerkeşi, 2020, ss. 269-273).

Hz. Âişe'nin eleştirisine yöneltilen bir başka eleştiri de şudur:

Hz. Ömer ve oğlu Abdullah b. Ömer başta olmak üzere bir grup sahabi Hz. Peygamber'den ölünün ailesinin ağlaması sebebiyle azap çekeceğine dair hadisi rivayet etmişlerdir (Buhârî, 2015, s. Cenâiz 33, II: 80-1; Müslim, 2016, c. Cenâiz 23-26, I: 641-643). Hz. Âişe ise buna: "Allah, Ömer'e rahmet eylesin. Hayır, vallahi Rasûlüllah (s.) Allah'ın bir mümine, birisinin ağlaması sebebiyle azap edeceğini haber vermedi. Lakin o şöyle buyurdu: 'Allah, ailesinin ağlaması sebebiyle kafirin azabını artırır.' Sonra
Âişe şöyle dedi: "Size (bu hususta) Kur'an yetmiyor mu? Hiçbir günahkâr, başkasının günah yükünü yüklenmez." (Necm, 53/38; En'âm, 6/164; İsrâ', 17/15; Fâtır, 35/18; Zümer, 39/7) Başka bir rivayette ise Hz. Âişe'ye Abdullâh b. Ömer'in, "Ölü, dirinin ağlamasıyla azap görür." dediği hatırlatılınca, şöyle demiştir: “Allah, Ebû Abdurrahmân’a rahmet eylesin, bir şey işitmiş, tam ezberleyememiştir. Rasûlüllah (s.) bir Yahûdî cenazesine uğramış, oradaki insanlar da ağlamaktaymış, bunun üzerine o (s.) 'Siz burada ağlaşıyorsunuz, o da azap çekiyor.' demiştir.” (Hişâm b. Urve-babasından bkz. Müslim, 2016, c. Cenâiz 25, I: 642, 2016, c. Cenâiz 26, I: 643).

İbn Kuteybe (ö. 276/889) mezkur ayetleri ileri sürerek Hz. Peygamber'den nakledilen bu hadise itiraz edenlere verdiği cevapta hadisin sahih olduğunu, Hz. Âişse'nin yaptı̆̆ itirazın ise geçersiz olduğunu belirtmekte ve şöyle demektedir: "Hz. Âişe bu hadise karşı çıkmış ve onu söyleyenin yanlış yaptığını belirtmiştir. Oysa bu, Hz. Âişe'nin zannı ve tevilidir. Rasûlullâh'ın (s) hadisine de zan ile karşı çıkmak caiz değildir. Eğer o, Rasûlullâh'tan (s) bir şey rivayet etmiş olsaydı, onun bu sözü kabul edilirdi. Şayet bunu sadece Abdullah b. Ömer tek başına nakletmiş olsaydı, yanıldığı söylenebilirdi. Oysa bunu aralarında Hz. Ömer, Imrân b. Husayn, İbn Ömer ve Ebû Musa el-Eş'arî'nin de bulunduğu sahabeden bir grup nakletmiştir." (İbn Kuteybe, 1999, ss. 101-103; Aş1k, 1981, ss. 264-267)

Zerkeş̂’ye göre ise Hz. Âişe'nin sözü Kur'an'ın zahirine muvafiktır. Aynı şekilde onun sözü, Hz. Peygamber'in bir grup ölüye ağlamas ${ }^{11}$, ölülere ağlanmasına karşı çıkmaması hakkında gelen diğer hadislere de uygundur. O (s.) âlemlere rahmet olarak gönderilmiştir, dolayısıyla ölülerin azap çekmesine sebebiyet verecek bir şey yapması veya böyle bir şeyi onaylaması muhaldir. Bu da, Hz. Âiş̧e hadisi için diğer bir tercih sebebidir (Zerkeşi, 2020, ss. 143-145, 185-188).

Kurtubî (ö. 671/1273) Hz. Âişe'nin bu eleştirilerine şöyle bir eleştiri getirmektedir: 'Hz. Âişe'nin bu hadise karşı çıkması ve ravileri hakkında hata etmek, unutmak yahut bir kısmını iştip bir kısmını işitmemekle hükmetmesi uzak bir ihtimaldir. Çünkü bu sahabeden bu anlamda hadisleri kesin olarak rivayet edenler çoktur. Dolayısıyla sahih bir yorum yapma imkanı varken hadisleri reddetmeye gerek yoktur." Konuyu geniş bir biçimde şerh eden İbn Hacer Kurtubî'den bu yorumu naklettikten sonra şu değerlendirmeyi yapmaktadır: "Bunlar, Hz. Âişe'den gelen farklı tevillerdir. Bunlardan anlaşılmaktadır ki o bu hadisi, başka bir hadis ile değil, aksine sadece Kur'an'a muarız gördüğünden dolayı reddetmektedir." (İbn Hacer, 1407, c. III: 1288-1289).

\section{5. Çağdaş Alimlerin Hz. Âişe'ye Yönelttiği Eleştiriler}

Hz. Âişe'nin, bazı rivayetler hakkında beyan ettiği kanaatleri, çağımızdaki kimi ilim adamları tarafından tasvip edilmemiştir. Onun açlıktan öldürdüğü bir kedi yüzünden azap edilen kadın ile ilgili Ebû Hureyre'nin rivayetini “Allah katında bir mümin, bir kedi yüzünden azap çekmeyecek kadar değerlidir, (ama) bu kadın (aynı zamanda) bir kafir idi”(İbn Kesîr, 1998, c. XXXVI: 306, h.no: 2468; Heysemî, 1979, c. IV: 188, h.no: 3506) diyerek düzeltmesi ile ilgili olarak Yusuf el-Karadâvî şöyle der: 
"Müminlerin annesi Âişe, hadisin bu sîgasıyla rivayetini, Ebû Hureyre'nin Hz. Peygamber'den işittiğinde, lafzını iyice belleyemediği zannı ile reddetti. Hz. Âişe'nin delili, bir kedi yüzünden mümin bir insana azap edilmesini çok görmesidir. Çünkü Allah yanında mümin, konuşmayan bir hayvan yüzünden cehenneme atılmayacak kadar değerlidir. Allah, Hz. Âişe'yi bağışlasın, burada gayet önemli bir şeyde gafil davranmıştır ki, o da, yapılan işin delalet ettiği husustur. Çünkü açlıktan ölünceye kadar kedinin hapsedilmesi, o kadının kalbinin donukluğuna, Allah'ın zayıf yaratıklarına karşı katılı̆̆ına, merhamet ışıklarının kalbine girmediğine dair en açık bir delildir. Cennete ise ancak merhametli olanlar girer. Allah ancak merhametli olanlara merhamet eder. Eğer o kadın yerdekilere merhamet etseydi, Yüce Allah da ona merhamet ederdi. Şüphesiz bu ve benzeri hadisler, insani değerler açısından İslam için övünç kaynağ 1 sayılmaktadır. Öyle ki, her canlı mahluka hizmet ediliyor, her yaş ciğer taşıyan canlıyı gözetmekten dolayı ecir veriliyor..."(Karadâvî, 1990, ss. 46-47)

$\mathrm{Bu}$ değerlendirmenin ardından Karadâvî, aynı hadisin, hem İbn Ömer (Buhârî, 2015, c. Ezân 90, I: 181-2; Müslim, 2016, c. Birr 133, III: 2022), hem de Câbir (Ahmed b. Hanbel, 1982, c. III: 335-6; Müslim, 2016, c. Kusûf 9, I. 622) tarafindan da rivayet edildiğini, ${ }^{12}$ dolayısıyla Ebû Hureyre'nin bu rivayetinde tek kalmadığını da ifade eder ki,(Karadâvî, 1990, ss. 46-47) bizce onun bu değerlendirmesi takdire şayandır. ${ }^{13}$

Şüphesiz, Hz. Âişe burada o kadının kafir olduğunu kendi kanaati olarak belirtmiştir. Ebû Hureyre'nin rivayeti eksik veya yanlış nakletmesi muhtemel ise de, İbn Ömer ve Câbir rivayetlerinin de aynı doğrultuda olması, aslında hadisin doğru olarak nakledildiğini gösterir.

Burada geçmişte olduğu gibi günümüzde de Hz. Âişe'ye Şiî alimler tarafindan yöneltilmiş birçok eleştiri olduğu malumdur. Ancak Şia'nın Hz. Âişe hakkında ileri sürdükleri hususlar, itiraz ve eleştiri olmaktan ziyade iftira ve çok ağır tihamlardan oluştuğu için onları bu meyanda değerlendirmeye almayı uygun görmediğimi belirtmeliyim.(Bu konuda müstakil bir çalışma için bkz. Askerî, t.y., s. 1 vd)

\section{Sonuç}

Hadislerin anlaşılması ve yorumlanması, sahabeden beri süregelen oldukça önemli ve bir o kadar da zor bir iştir. Eda ve tahammül (alma ve nakletme) esnasında yaşanan küçük bir hata, hadisin kabulünü güçleştirebilmekte hatta gereksiz yere reddedilmesine sebep olabilmektedir.

Hz. Peygamber'in evinde ve elinde yetişen, ilmi yönü, rivayeti ve dirayeti ile şöhret kazanmış olan Hz. Âişe dahi, işitttoği bazı rivayetleri değerlendirirken oldukça isabetli tenkitlerinin yanısıra, bazen ulemayı şaşırtacak derecede yanılgılara düşebilmiştir. Onun hem isabetli eleştirileri, hem de eleştirilerinde düştüğü yanılgıları, sonraki alimler tarafindan daima tartışılmış ve değerlendirilmiştir.

Yukarıda verdiğimiz örnekler de ortaya koymaktadır ki, nakledilen bir hadisi yeterince araştırıp doğru anlaşılması ve yorumlanması için gerekli çabalar sarfetmeden bir çırpıda

\footnotetext{
${ }^{12}$ Ayrıca Abdullâh b. Amr tarafından da rivayet edilmiştir (Nesâî, 2010, c. Kusûf 20, III. 149).
}

reddetmek yahut fevri bir çıkışla hemencecik itiraz etmek Hz. Âişe gibi Allah Rasûlünü en yakından tanıyanları bile hataya düşürebilmektedir. $\mathrm{Bu}$ nedenledir ki, hadisleri değerlendirirken, yorumlarken oldukça dikkatli olmak gerekmektedir.

Dönemi gereği Hz. Âişe'nin istidrâklerinde isnad değil, metin kritiği öne çıkmaktadır. Dolayısıyla özellikle günümüzde metin tenkidi yapılırken, ortaya atılan metin tenkidi kriterlerini yanlış kullanmamak gerekmektedir. Hadislerin Kur'an'a arzında dikkat edilmesi gereken birtakım hususlar ve karşılaşılan bazı problemlerin varlığı inkar edilemez (Polat, 2017, ss. 186-187, 239-247; Keleş, 1998, ss. 193-257; Kırbaşoğlu, t.y., ss. 427-441; Kamil, 1995, ss. 237-262; Şimâlî, 1996, ss. 217-236). Bu nedenledir ki, Hz. Âişe'nin Kur'an'a arz uygulamalarının tümünde de isabetli olduğunu söylemek mümkün gözükmemektedir. Nitekim bazı ilim adamları ona itiraz etmiş, onun yanıldığını söylemekten geri kalmamışlardır. Karşılıklı istidrâklere bakıldığında, Hz. Âişe'nin daha çok metni ve muhtevayı esas aldığı, ona itiraz eden alimlerin ise isnadların sahih olmasını ve farklı tariklerden gelmesini öne çıkardıkları anlaşılmaktadır.

Rivayetlere yönelttiği eleştirilerinin bir kısmında Hz. Âişe, Hz. Peygamber'in söz ve fiiline bizzat şahid olmadığı halde, O'nu en yakından tanıyan birisi olarak, kişisel kanaatine ve tahminine dayalı yorumlar yapmıştır. Özellikle aynı hadis hakkında ondan farklı izahların gelmiş olması, veya ona atfen bazı haberlerin nakledilmesi, tevil ihtimalini kuvvetlendirmektedir. Bu sebeple onun, "Hz. Peygamber böyle dememiştir, dese dese şöyle demiştir" anlamındaki bazı düzeltmeleri, selef alimlerinin bazıları tarafından tasvip ve kabul görmemiştir.

$\mathrm{Bu}$ itirazlara rağmen Hz. Âişe'nin esas aldığı kriterler, günümüz metin tenkidi çalışmalarındaki vazgeçilmez ölçüleri oluşturmaktadır. Onun bazı istidrâkleri kabul görmese de, metin tenkidi sahasında uygulamış olduğu metodu, kullanmış olduğu kriterleri son derece önemlidir. Hz. Âişe birçok istidrâkinde, metin tenkidinin en güzel örneklerini vererek bu sahada kendisinden sonra gelen nesillere öncülük etmiş, çığır açmıştır.

“Hz. Âişe'nin bir hadisçi olarak esas değerini ortaya koyan hizmeti, zamanındaki ilim adamı sahabilerin fetva ve rivayetlerinde düştükleri hatalara karşı yürüttüğü tashih ve tenkid faaliyetidir. Rasûlullâh'ın vefatından sonra tam kırk yedi sene sürdürdüğü bu ilmi faaliyet, onun Kur'an ve sünnet bilgisinin ne kadar kuvvetli olduğunu, sahip olduğu muhakeme, tenkid kabiliyeti ve ilmî seviyesini göstermektedir.

$\mathrm{Bu}$ tenkid faaliyetleri o devrin ilmî zihniyetini göstermesi bakımından da ayrıca önem taşır. Onun bu tenkidleri yerine göre çok şiddetli olmuştur. Ancak hedef doğru ve sağlam olanın ortaya çıkması, dinin en güzel biçimde anlaşılmasının sağlanması olduğu için daima müsbet sonuçlar vermiştir." (Aşık, 1987, ss. 6, 69).

Hz. Âişe vâlidemizin, temelini attığı "muhteva tenkidi" ile sahih Hadis ve Sünnet'in tesbiti, aslında zor ama son derece gerekli bir görevdir. Günümüz hadisçileri için de vazgeçilmez bir yöntem olduğuna inandığımız benzer yaklaşımlarla,

13 Keleş ise, Hz. Âişe'nin hadisi reddetme gerekçesinin Karadâvî'nin dikkatinden kaçtı̆̆ını söyleyerek onun bu değerlendirmesine katılmamaktadır (Keleş, 1998, ss. 209-210). 
Rasûl-i Ekrem'e ait olan Sünnet ve Hadis bilgilerinin daha sağlıklı bir şekilde tesbiti, daha makul bir şekilde anlaşılıp yorumlanması müyesser olacaktır.

Sonuç olarak, eleştiren ilim adamlarının zaman zaman karşı eleştirilere maruz kalmaları da kaçınılmazdır. Burada önemli olan, doğrunun, hakikatin ortaya çıkması adına ilim ahlâkına yakışır bir tavır koyabilmek, eleştiri kültürüne de, tahammül ahlâkına da sahip olabilmektir. İslam düșüncesindeki söz konusu ilmi gelenek, Hz. Âişe de olsa bazı yorum ve yaklaşımlarının sonraki alimlerce eleştirilmesine engel teşkil etmemiş ve birçok alim tarafından onun görüşleri açık yüreklilikle eleştirilebilmiştir. Bugün ilim adamlarına düşen de, geçmiş ilmi kültürü hatasıyla sevabıyla tekrarlama yerine, görülen birtakım hataların ilmi üslup çerçevesinde eleştirilmesi ve böylece hakikatin ortaya çıkmasının sağlanması olmalıdır. Reddiye, eleştiri, itiraz geleneği oldukça güçlü olan bir ilim geleneğinin bugünkü temsilcilerinin de aynı geleneği sürdürmeleri gerekmektedir. Özellikle son yıllarda artan birçok akademik çalışmaya rağmen, nitelikli eleştirilerin adeta yok mesabesinde olduğu herkesin malumudur. İşte bu noktada Hz. Âişe annemiz, hem başkalarını eleştiren, hem de birçok alim tarafından bazı görüşleri eleştirilen ideal bir örnek teşkil etmektedir. Ve ilim erbab1, onun hem eleştirilerinden, hem de eleştirildiği hususlardan istifade etmektedir.

\section{Kaynakça}

Abdurrezâk, E. B. b. H. b. N. el-Himyerî es-San'ânî. (1403). El-Musannef. Beyrut.

Ahmed b. Hanbel, E. A. A. b. M. b. H. eş-Şeybânî elMervezî. (1982). Müsned. İstanbul.

Askerî, M. el. (t.y.). Ehâdîsu Ümmi'l-Mü'minîn 'Âişe. Beyrut: et-Tevhîd li'n-Neşr.

Aşık, N. (1981). Sahabenin Hadis Anlayışı. İzmir.

Aşık, N. (1987). Hazreti Âişe’nin Hadisçiliği. İzmir.

Buhârî, E. A. M. b. İ. el-. (2015). Sahîh. Beyrut: Müessesetü'r-Risâle Nâşirûn.

Dârekutnî, E.-H. A. b. Ö. (1966). Sünen.

Ebû Dâvûd, S. b. E. b. İ. b. B. b. Ş. b. 'Amr el-E. es-Sicistânî. (2009). Sünen (1. Bask1, C. 1-7). Beyrut: Dâru'r-Risâle el-'Âlemiyye.

Ebû Ubeyd, el-K. b. S. (1964). Ğarîbu'l-Hadîs. Haydarâbâd.

Görmez, M. (2000). Sünnet ve Hadisin Anlaşılması ve Yorumlanmasinda Metodoloji Sorunu. Ankara: Türkiye Diyanet Vakfi Yayınları.

Hâkim en-Nisâbûrî, M. b. A. (1990). El-Müstedrekü ala'sSahîhayn. Beyrut: Dâru'l-Kutubi'l-İlmiyye.

Hattâbî, E. S. H. b. M. (t.y.). Meâlimu's-Sünen.

Heysemî, A. b. E. B. (1979). Keşfu'l-Estâr an Zevâidi'lBezzâr. Beyrut.

İbn Ebî Şeybe, E. B. A. b. M. b. E. Ş. İ. el-Absî el-Kûfî. (2006). El-Musannef (1. Bask1). Beyrut: Dâru'l-Kıble.

İbn Hacer, E.-F. Ş. A. b. A. b. M. el-Askalânî. (1407). Fethu'l-Bârî bi Şerhi Sahîhi'l-Buhârî (3. Baskı). Kâhire: el-Mektebetu's-selefiyye.
İbn Huzeyme, E. B. M. b. İ. (1988). Kitâbu't-tevhîd ve isbâtu slfâti'r-rabb 'azze ve celle. Riyâd.

İbn Kayyim el-Cevziyye, E. A. Ş. M. b. E. B. b. E. ez-Züraî ed-Dımaşkī el-Hanbelî. (1994). Zâdu'l-Me'âd (27. Bask1, C. 1-5). Beyrut: Müesesetü’r-Risâle.

İbn Kesîr, E.-F. (1998). Câmi 'u'l-Mesânîd.

İbn Kuteybe, A. b. M. (1999). Te 'vîlu muhtelifi'l-hadîs. y.y.: el-Mektebu'l-İslâmî.

İbn Mâce, M. b. Y. (2010). Sünen. Beyrut: Müessesetü’rRisâle Nâşirûn.

İbn Sa'd, M. (2002). Kitâbu't-tabakâti'l-kebîr. Kâhire: Mektebetü'l-Üsre.

İbn Teymiyye, E. A. T. A. b. A. (2004). Mecmûu'l-Fetâvâ. Medine: Matbaatü Melik Fahd.

İdlîbî, S. el-. (2013). Menhecü nakdi'l-metn 'inde 'ulemâ'il-hadîsin'-Nebevî. Kâhire: Dâru'l-Feth.

Kamil, Ç. (1995). Hadisin Kur'an'a Arzı Meselesi. Ankara Üniversitesi Illahiyat Fakültesi Dergisi, 34(1), 1. https://doi.org/10.1501/Ilhfak_0000000797

Karadâvî, Y. (1990). Keyfe Neta'âmel Ma'â's-Sunneti'nNebeviyye, Ma 'âlim ve Davâbit. Mansure: Dâru'l-Vefâ.

Keleş, A. (1998). Hadislerin Kur'an'a arzı (4. Baskı). İstanbul: İnsan Yayınları.

Kırbaşoğlu, H. (t.y.). Hadis Illminde Metodoloji Sorunu (Basılmamış 2. Kısım).

Mâlik, E. A. M. b. E. b. M. (1985). Muvattâ. Beyrut: Dâru İhyâi't-Turâsi'l-Arabî.

Mehmed Said, H. (1971). Hazret-i Aişe'nin Hadis Tenkidciliği. Ankara Üniversitesi Ilahiyat Fakültesi Dergisi, 19(1), https://doi.org/10.1501/Ilhfak_0000000484

Müslim, E.-H. M. b. el-Haccâc. (2016). Sahîh. Beyrut: Müessesetü'r-Risâle Nâşirûn.

Nesâî, A. b. Ş. en-. (2010). Sünen. Beyrut: Müessesetü'rRisâle Nâşirûn.

Nevevî, E. Z. Y. b. Ş. en-. (1392). el-Minhâc şerhu Sahîh'i Müslim b. El-Haccâc. Beyrut: Dâru İhyâi't-Turâsi'lArabî.

Polat, S. (2017). Hadis Araştırmaları. İstanbul: Kimlik Yayınları.

Râmehurmûzî, H. b. A. er-. (1971). El-Muhaddisu'l-fâsıl beyne'r-râvî ve'l-vâî'. Beyrut: Dâru'l-Fikr.

Sağlam, İ. (2017). 'Uğursuzluk Üç Şeydedir...' Rivayetinin İsnad ve Metin Yönünden Tahlili. Kırıkkale Íslami İlimler Fakültesi Dergisi, 2(3), 81-108.

Süheylî, A. (t.y.). Er-Ravdu'l-Ünf. Kâhire.

Şimâlî, Y. A. eş-. (1996). Arzu'l-Hadîs 'ale'l-Kur'ân. Mecelletu Dirâsâti Ululumi 'ş-Şeria ve'l-Kânûn, 23(2).

Şimâlî, Y. A. eş-. (1997). Simâu'l-Meyyit fî Dav'i'l-Kitâbi ve's-Sünne. Mecelletu Dirâsâti Ulûmi'ş-Şerîa ve'lKânûn, 24(2).

Şimâlî, Y. A. eş. (1999). Cem 'u'l-Müfterak mine'l-Hadîsi'nNebeviyy. Ammân: Dâru'l-Furkân.

Tayâlisî, bû D. S. b. D. b. el-Cârûd et. (1321). Müsned. Haydarâbâd. 
Tirmizî, M. b. ‘İsâ et-. (2015). Sünen. Beyrut: Müessesetü’rRisâle Nâşirûn.

Zehebî, Ş. E. A. M. b. A. ez-. (1985). Siyeru a'lâmi'nnübelâ. Beyrut: Müessesetü'r-Risâle.

\section{Extended Abstract}

Thanks to the education and training given by the Prophet, it is known by everybody that the critical mindset is very lively among the Companions. Hz. Aisha is undoubtedly the most prominent figure of this mentality. With her sharp intelligence and judgment, her desire to learn, and her ability to ask and question the truth, she stood out in the time of the Prophet.

Owing to her masterence of the Quran, Sunnah, Sira and Hadise, virtue of her mind, reasoning and horizon; she corrected many misunderstandings, interpretations and misrepresentations that emerged in both the sahaba and tabiun generations on many issues. Her revisions and criticisms, which were later called "istidrâk", opened a good era for those who came after her, and in the following centuries these istidraqs of her became the subject of independent copyrights. Abu Mansur al-Baghdadî (d. 489/1096) made the first copy in this field, and Bedruddîn ez-Zerkeşî (d. 794/1392) made the most extensive work on this subject. In modern times, various studies have been carried out on this aspect of $\mathrm{Hz}$. Aisha.

Actually, Hz. Âişe was not only criticizing, but she was subjected to various criticisms both in her own period and in the following centuries. Some of her views, especially was criticized by The Prophet and Companions and some scholars in the next period. In this study, we will mostly deal with the criticisms made to $\mathrm{Hz}$. Aisha. Thus, we will try to demonstrate, with the example of $\mathrm{Hz}$. Âişe, that the critic can also be criticized. The many examples we will give will clearly show what a vibrant culture of criticism and tolerance morality in Islamic thought.

Before we get into the subject, we should immediately state that; We will not try to determine who is right and more accurate in mutual "istidraqs" (whether it be a companion or the next ulama) that emerge on quite different issues. It will be appreciated that many evidences have been put forward on this subject until today and many conflicts have arisen from the Companions to the present. For this reason, examining the discussions and deciding which side is the most appropriate will go beyond the limits of such a communique. The point we want to put forward in this communique is to show that various istidraqs were directed to $\mathrm{Hz}$. Aisha, who is famous for her many istidraqs towards the Companions and Tabiun, and to draw attention to some points within this framework. The scope of the concept of "istidrâk" in our paper will be quite wide, including answering the question, trying to comprehend a matter, objecting, correcting, explaining and finally criticizing. We will examine the subject with the various examples we will give, under the following four headings:

1. Istidraks that the Prophet directed to Hz. Aisha,

\section{Istidraqs directed by the Companions to Hz. Aisha,}

3. Istidraks directed to Hz. Aisha by the Ancient Scholars,

\section{Istidraqs directed by Contemporary Scholars to Hz. Aisha}

Even Hz. Aisha, who grew up in the house and in the hands of the Prophet, gained fame with her "scientific aspect", "narration" and "wisdom", beside her quite accurate criticisms she made mistakes sometimes that confusing for the ulema while evaluating some of the rumors she heard. Her accurate criticism and her mistakes in her criticism have always been discussed and evaluated by later scholars.

The examples we have given above reveal the following. Rejecting a hadith that is reported, without making the necessary efforts to understand and interpret it correctly, or immediately object with an
Zerkeşi, E. A. B. M. b B. b A. (2020). Hz. Aişe'nin Sahabeye Yönelttiği Eleştiriler (B. Erul, Çev.). Ankara: Otto Yayınları.

impulsive stance, can make even those who know our Prophet the most closely, such as Hz. Aisha, into mistake. For this reason, it is necessary to be very careful while evaluating and interpreting hadiths.

Due to her period, text criticism, not isnad, stands out in the istidrâk of Hz. Aisha. Therefore, it is necessary not to misuse the text criticism criteria, especially when criticizing text today. There are some issues to be considered and some problems encountered while presenting the hadiths to the Quran. For this reason, it does not seem possible to say that $\mathrm{Hz}$. Aisha is correct in all presenting applications of the Qur'an. As a matter of fact, some scholars objected to her and did not hesitate to say that she was wrong. Looking at the mutual istidraqs, it is understood that $\mathrm{Hz}$. Aisha bases more on text and content, the scholars who objected to her emphasize that the isnads are valid and come from different sects.

Hz. Aisha did not witness the words and deeds of the Prophet himself in some of her criticisms of the rumors. Despite this, as someone who knew him best, she made comments based on her personal opinion and guess. Especially the fact that different explanations about the same hadith came from her, or that some news were reported in reference to it, strengthen the possibility of interpretation. For this reason, some of her corrections, which mean "the Prophet did not say that, if he said he said that" were not approved and accepted by some of the Salaf scholars.

Despite these objections, the measures taken as basis by Âişe are accepted as indispensable measures in today's text criticism studies. Although some of her istidraqs are not accepted, the method she applied in the field of text criticism and the criteria that she used are extremely important. Hz. Aişe gave the best examples of text criticism in many istidrâks. She pioneered the next generations in this field and broke ground.

The service that reveals the essential value of $\mathrm{Hz}$. Aisha as a hadithist is the correction and criticism against to the mistakes of the Companion Scientists of her time that they made while making fatwa and narration. She continued this scientific activity for fortyseven years after the death of the Prophet. This shows how strong his knowledge of the Qur'an and sunnah is, her reasoning, her ability to criticize and her scientific level.

These activities of criticism are also important in terms of showing the scientific mentality of that period. Her criticisms were very severe, depending on the place. However, since the goal was the emergence of the right and sound and the best understanding of religion, it has always yielded positive results. It is actually a difficult but extremely necessary task to determine the authentic Hadith and Sunnah, thanks to the "content criticism", which our mother Aisha laid the foundations of. This method will also be indispensable for today's hadithists. In this way, it will be easier to determine the Sunnah and Hadith information belonging to the Prophet in a healthier way and to understand and interpret them in a more reasonable way.

As a result, it is inevitable that the critical scientists will be subjected to counter-criticism from time to time. The important thing here is to be able to adopt an attitude befitting the ethics of science in order to reveal the truth; To have a culture of criticism and a moral of endurance. This scientific tradition in Islamic thought shows that even Hz. Aisha could be criticized by later scholars for some of her interpretations and approaches. Today, the duty of scholars is not to repeat the past knowledge culture with its merits, but to criticize some mistakes within the framework of a scientific style and thus, to ensure the emergence of the truth. Today's representatives of a scientific tradition, which has a strong tradition of rejection, criticism, and objection, must continue the 
63 Erul, B./ Anemon Muş Alparslan Üniversitesi Sosyal Bilimler Dergisi, 2021 9(IDEKTA) 53-62

same tradition. At this point, our mother Aisha is an ideal example, both criticizing others and criticizing some of her views by many scholars. Scientists benefit from both her criticism and the points she criticized. 